\title{
ZDRAVSTVENO STANJE URBANOG DRVEĆA SARAJEVA S POSEBNIM OSVRTOM NA ŠTETE OD SNIJEGA
}

\author{
The health status of urban trees in Sarajevo with special retrospect \\ on damages caused by snow
}

\author{
Osman Mujezinović ${ }^{1}$, Azra Čabaravdić ${ }^{1}$ Tarik Treštić $^{1}$ i Mirza Dautbašić ${ }^{1}$
}

\begin{abstract}
This paper analyzes the health status of trees in the avenues of the city of Sarajevo. Special attention is paid to abiotic harmful influences, snow precipitation and mechanical damage of trees, as the initial factors of destabilization of their health status.

Sarajevo area is characterized by a moderate continental climate occurring as a result of the influence of central European climate from the north and the Mediterranean climate from the south and of the variety of the terrain. This type of climate is characterized by hot summers and relatively cold winters. Because of severe thermal influence of the Adriatic Sea autumn is warmer than spring. Distribution of precipitation in Sarajevo is characterized by summer (primary) and autumn (secondary) peaks. Specific weather conditions in this area, in some years, result in early or late snowfall the consequences of which are damages of vegetation cover.

The results of this research confirmed significant damages of the trees resulted from the adverse effects of snow in October 2009 (branches fractures, split of the stem and fracture of tree crowns). The resulting injuries are suitable openings for the penetration of rot causing microorganisms (fungi and bacteria) and colonization of insects which is why we can expect further deterioration in the health status of trees in the future. The paper suggests activities the implementation of which can reduce these harmful effects of biotic factors.
\end{abstract}

Key words: health status, urban trees, damages caused by snow, linking up of biotic and abiotic factors

\section{Izvod}

U ovom radu analizirano je zdravstveno stanje stabala u drvoredima grada Sarajeva. Posebna pažnja posvećena je abiotičkim štetnim uticajima, sniježnim padavinama i mehaničkim oštećenjima drveća, kao početnim faktorima destabilizacije njihovog zdravstvenog stanja.

\footnotetext{
${ }^{1}$ Šumarski fakultet u Sarajevu - Faculty of Forestry, University of Sarajevo
} 
Područje Sarajeva se odlikuje umjereno kontinentalnom klimom nastalom kao rezultat uticaja srednjoevropske klime sa sjevera i mediteranske klime sa juga te raznovrsnošću reljefa. Ovaj tip klime karakterišu topla ljeta i relativno hladne zime, a zbog izraženog termičkog uticaja Jadranskog mora jesen je toplija od proljeća. Raspored padavina u Sarajevu odlikuje se ljetnim (primarnim) i jesenjim (sekundarnim) maksimumom. Specifične vremenske prilike na ovom području, u pojedinim godinama, rezultiraju uranjenim ili zakašnjelim snježnim padavinama čije posljedice su štete na biljnom pokrivaču.

Provedenim istraživanjima utvrđena su značajna oštećenja drveća nastala kao posljedica štetnog djelovanja snijega u oktobru 2009. godine (prelomi grana, prelomi debla i rascjep krošnje). Nastale povrede pogodni su otvori za prodor uzročnika truleži (gljive i bakterije) i naseljavanje insekata zbog čega se može očekivati dodatno pogoršanje zdravstvenog stanja drveća u narednom periodu. U radu se sugerišu aktivnosti čijom provedbom se mogu umanjiti navedeni štetni uticaji od biotskih faktora.

Ključne riječi: zdravstveno stanje, urbano zelenilo, snjegolomi, ulančavanje štetnih biotičkih i abiotičkih faktora

\section{UVOD - Introduction}

Drveće u nasljenim mjestima od velike je važnosti za život čovjeka. Ono doprinosi stvaranju ugodnog ambijenta, prečišćava zrak, smanjuje koncentraciju $\mathrm{CO}_{2}$, stvara povoljnu mikroklimu, umanjuje buku, pruža doživljaj prirode i sl. Zbog toga je uobičajeno da se funkcije urbanog zelenila sagledavaju kao: biološko-sanitarnohigijenske, dekorativno-estetske, kulturno-obrazovne, rekreativne i ekonomske (LJUJIĆ - MIJATOVIĆ I MRDOVIĆ, 1988).

Neophodan uslov za ispunjenje svih očekivanih funkcija drveća $u$ gradskom zelenilu je njegovo dobro zdravstveno stanje. Posebno je značajan uticaj ekoloških faktora kao što su: sunčeva energija, čist zrak i kvalitet tla. Zbog specifičnosti nastanka i razvoja urbanih prostora ovi faktori su često deficitarni za biljke. Na stabilnost i vitalnost urbanog zelenila utiču brojni biotički i abiotički agensi (KANTIĆ ET AL., 2009; TOMICZEK ET AL.. 2008; TREŠtIĆ ET AL., 2008, 2007 I 2003; DIMINIĆ I HRAŠOVEC, 2005; DAUTBAŠIĆ ET AL., 2004; MATOŠEVIĆ, 2003). Drveće gradskog zelenila se, za razliku od onog u prirodnim staništima, razvija u tlu koje je izloženo zasoljavanju tokom zimskih mjeseci i drugim vrstama zagađenja. Osim ovih poteškoća, biljke u gradskim sredinama su izložene i specifičnom nepovoljnom djelovanju atmosferilija (snijeg, vjetar, kiša i dr.). Njihov negativan uticaj značajnije se ispoljava na nestručno i nepravilno oblikovanim krošnjama drveća. Za zdravstveno stanje drveća iz ove grupe nepovoljnih abiotskih uticaja najvažniji je snijeg. Prema VALINGER ET AL. (1993) otpornost drveća prema štetnom dejstvu snijega zavisi od vrste drveta, starosti, karakteristika stabla, kvaliteta provođenih uzgojnih mjera te kombiniranog uticaj temperature, vjetra i snijega.

Biološke karakteristike vrste drveta opredjeljuju izgled i oblik njegove krošnje a time i njenu otpornost na mehanička naprezanja. Za područje Evrope općenito 
vrijedi da su lišćarske vrste, u pogledu oštećenja od snijega, osjetljivije od četinarskih (ROTTMANN, 1985). Ove razlike definisane su modelom elastičnosti, zatim nejednakim kapacitetom grana za prihvat snijege te razlikama u habitusu (PELTOLA ET AL., 1997). Prema Petersonu (2004) stabla srednjeg uzrasta bolje podnose štetno djelovanje snijega i vjetra od manjih ili robusnih. Općenito, veličina krošnje, forma i zašiljenost (koničnost) su osobine koje uvjetuju otpornost drveća prema snjegolomima. Drveće sa asimetričnom krošnjom podložnije je oštećenjima zbog naglašenog debalansa $u$ njenom opterećenju (PERTILLÄ, 1987). Uske krošnje su otpornije od onih drugačije forme, jer je površina njihove horizontalne projekcije manja. Ovo ima za posljedicu manju akumulaciju snijega u krošnji a time i slabije opterećenje. Što se tiče zašiljenosti krošnje, otpornost na snjegolome je veća kod visokih i koničnih krošanja sa ravnim stranama (MATTHEWS, 1989).

Otpornost urbanog drveća nekog lokaliteta prema snjegolomima uveliko zavisi i od pravilnog izbora provenijencije sadnog materijala. Vrste porijeklom iz južnih ili lokaliteta sa nižim nadmorskim visinama će biti podložnije snjegolomima ukoliko se uzgajaju na sjevernijim i višim (hladnijim) područjima (MEGAHAN I STEELE, 1987). I veličina stanišnog prostora koji zauzimaju krošnje stabala utiče na otpornost drveća prema djelovanju mehaničke sile snijega i vjetra ili pak njihovog sadejstva. Kvalitetno provodenim uzgojnim mjerama postiže se bolja srazmjera prečnika i visine drveća čime se umanjuje osjetljivost jedinke na prelome debla.

Osnov štetnog dejstva snijega čini opterećenje na savijanje grana i cijele krošnje iznad dozvoljenog praga koje se javlja kao posljedica njegove akumulacije na ovim organima. Pri tome opterećenje stabala dodatno raste pri vjetrovitom vremenu. Tip snijega, od čega najviše zavisi njegovo nakupljanje na krošnjama drveća, predodređen je vremenskim prilikama, prije svega temperaturom zraka i brzinom vjetra (SOLANTIE, 1994). Pri povišenim temperaturama, sadržaj vode u snijegu raste što utiče na njegovu gustoću. Prema JACKSONU (1977) veličina ovog parametra kreće se u granicama od 0,05 do $0,40 \mathrm{~g} / \mathrm{cm}^{3}$. Vlažan snijeg najčešće se pojavljuje u kasnu jesen ili rano proljeće (NYKÄNEN ET AL., 1997).

Manifestacija štetnog dejstva snijega ogleda se u prelomu grana te prelomu i rascjepu debla. Mjesto preloma u krošnji zavisi od njene zašiljenosti, čvrstoće drveta, te prisustva nedostataka kao što su kvrge i truleži. Stablo na kojem se javi prelom debla neposredno ispod žive krošnje gubi svoju ulogu kao objekat urbanog zelenila. U slučaju manjeg oštećenja krošnje, posljedice po stablo su umanjena vitalnost i veća osjetljivost prema narednim snjegolomima. Urbano drveće koje je pretrpjelo oštećenje od snijega manje je stabilno, često je iskrivljeno i višestruko razgranato (NOROKORPI I KÄRKKÄINEN, 1985). Period oporavka oštećenih stabala traje različito, a zavisi od mjesta (visine) preloma, površine oštećenja, starosti i vrste drveta (WILLINSTON, 1974). Oštećeno stablo pogodnije je za razviće uzročnika bolesti i truleži i naseljavanje insekata od zdravog i vitalnog. Ovi, naknadni, procesi dodatno utiču na zdravstveno stanje i dužinu životnog vijeka oštećene jedinke (TREŠTIĆ ET AL., 2008; DAUTBAŠIĆ ET AL., 2004; VALINGER I LUNDQUIST, 1994; ROTTMANN, 1985). 


\section{MATERIJAL I METODE RADA - Material and methods of work}

Područje istraživanja u ovom radu odnosi se na drvorede Sarajeva duž sljedećih glavnih saobraćajnica: Vilsonovo šetalište, Bulevar Meše Selimovića (dio od Doma zdravlja Kumrovec do RTV doma) i Alipašina ulica (od Alipašine džamije do Ciglana). Sarajevo se odlikuje umjereno kontinentalnom klimom koja je nastala kao rezultat uticaja srednjo-evropske klime sa sjevera, mediteranske klime sa juga i raznovrsnog reljefa. Ovaj tip klime karakterišu topla ljeta i relativno hladne zime. Zbog izraženog uticaja Jadranskog mora, jesen je toplija od proljeća. Veličine klimatskih elemenata koji karakterišu ovaj tip klime za Sarajevo su sljedeće: srednja godišnja temperatura $9.5{ }^{\circ} \mathrm{C}$, apsolutna minimalna temperatura u januaru $-21{ }^{\circ} \mathrm{C}$, apsolutna maksimalna temperatura u avgustu $37,4^{\circ} \mathrm{C}$, godišnja količina padavina 932 $1 / \mathrm{m}^{2}$, trajanje perioda sniježnih padavina 170 dana. Složena reljefna izgrađenost područja uslovljava vazdušna strujanja koja su različita po pravcu i brzini. Dominantni vjetrovi su oni koji pušu iz jugoistočnog odnosno zapadnog kvadranta.

Cilj istraživanja bio je utvrđivanje intenziteta oštećenosti stabala u drvoredima nastalih pod uticajem snijega te procjena uticaja nastalih oštećenja na opće zdravstveno stanje povrijeđenih jedinki. Pri istraživanju pošlo se od hipoteza: (1) da ne postoje statistički značajne razlike u otpornosti različitih vrsta drveća prema snjegolomima i (2) da ove razlike nisu uslovljene uzrastom drveća iste vrste.

Prikupljanje podataka o snijegom oštećenim stabalima izvršeno je u tri sarajevska drvoreda u oktobru 2009. godine. Pri tome je ukupno pregledano i ocijenjeno 861 (Vilsonovo šetalište 323, Bulevar Meše Selimovića 274 i Alipašina ulica 264) stablo. Za stabla navedenih objekata koja su obuhvaćena ovim analizama utvrđena je vrsta drveta, izmjeren prsni prečnik i ocijenjen stepen oštećenosti po tipu povrede. Pod oštećenjima stabla u smislu ovih istraživanja smatrano je sljedeće: prelom debla (povreda koja podrazumijeva gubitak cijele krošnje), rascjep krošnje (povreda pri kojoj se je jedna ili više glavnih grana krošnje odvojila od centralne osovine debla) te prelom grane ili više njih (povrede na dijelu grane iznad mjesta na kojem su povezane sa deblom). Na osnovu prikupljenih informacija provedena je statistička obrada podataka, analiza i interpretacija dobijenih rezultata. Za testiranje postavljenih hipoteza primjenjen je $\chi^{2}$-kvadrat test. Pri tome su korištene tabela kontigencije vrsta drveća prema prisutnim oštećenjima i tabele kontigencije prisutnih oštećenja po debljinskim stepenima unutar iste vrste. Kod vrsta s malim brojem pojave oštećenja po debljinskim stepenima podaci su grupisani u dvije katogorije i primjenjen je Mc Nemar $\chi^{2}$-kvadrat test razlika proporcija (ZAR, 1995).

\section{REZULTATI - Results}

Prema naprijed definisanoj metodici istraživanja, mjerenja i ocjene parametara provedena su na 861 stablu. Raspodjela ovih stabala po navedenim pokazateljima prikazana je u tabeli 1 . i 3. te histogramu 1. 


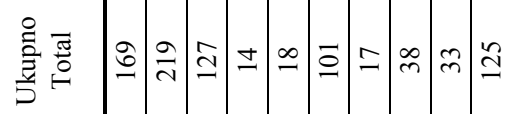

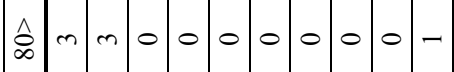

2000000

$=000000$

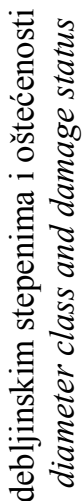

हี

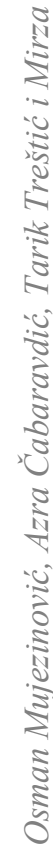

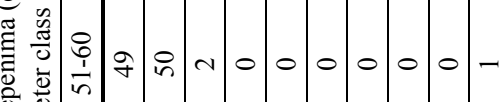
कू क्षे

寻

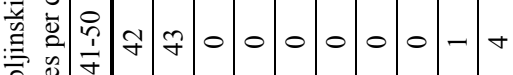

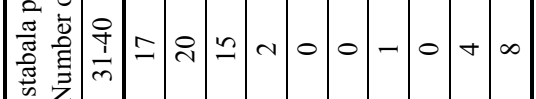
ติ

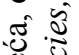

की

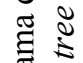

党

\&

$\frac{\pi}{2} \pm$

กิ

㻤

용

ह

\&

$-i$

ㅎํㄴ

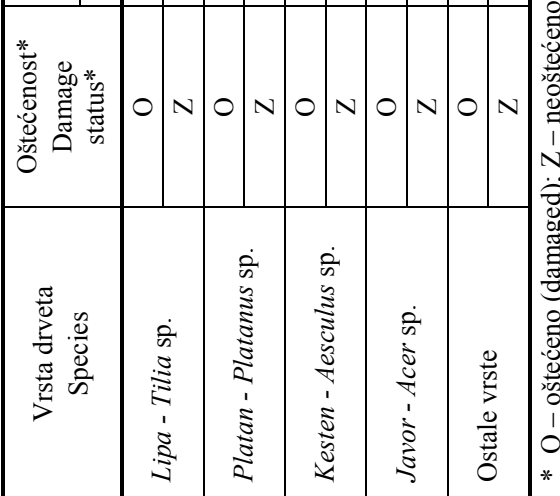

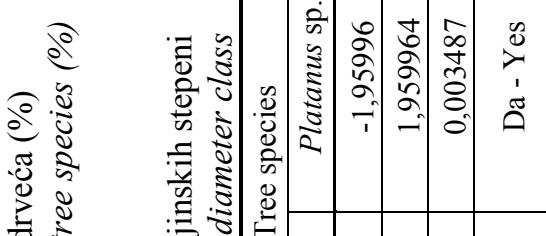

ש

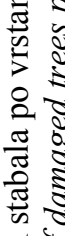

등

ల్ల

究

造

瓷

$-$

छ

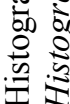

I

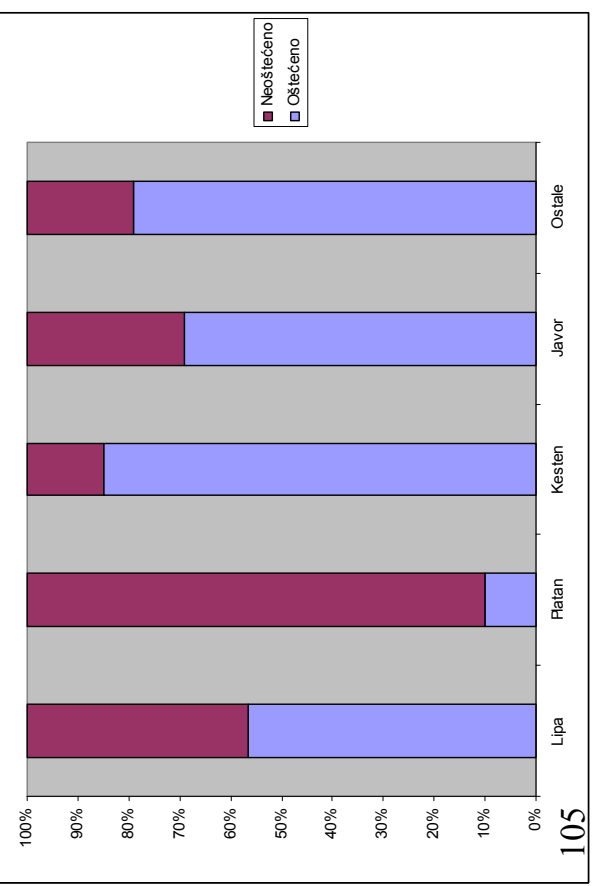


Tabela 3. Raspodjela broja stabala po vrstama drveća i tipu oštećenja Table 3 The distribution of trees per tree species and type of damage

\begin{tabular}{|l|c|c|c|c|c|c|c|}
\hline \multirow{2}{*}{$\begin{array}{c}\text { Vrsta } \\
\text { drveta } \\
\begin{array}{c}\text { Tree } \\
\text { species }\end{array}\end{array}$} & $\begin{array}{c}\text { Ukupno } \\
\text { Total }\end{array}$ & $\begin{array}{c}\text { Neoštećena } \\
\text { Undamaged }\end{array}$ & $\begin{array}{c}\text { Oštećena } \\
\text { Damaged }\end{array}$ & $\begin{array}{c}\text { Prelom } \\
\text { debla } \\
\text { Stem } \\
\text { fracture }\end{array}$ & $\begin{array}{c}\text { Rascjep } \\
\text { krošnje } \\
\text { Split of } \\
\text { crown }\end{array}$ & $\begin{array}{c}\text { Trelom } \\
\text { grana } \\
\text { Branch } \\
\text { fracture }\end{array}$ & $\begin{array}{c}\text { Višestruka } \\
\text { oštećenja } \\
\text { Multiple } \\
\text { damages }\end{array}$ \\
\hline Tilia & 388 & 219 & 169 & 44 & 15 & 137 & 30 \\
\hline Platanus & 141 & 14 & 127 & 63 & 29 & 88 & 62 \\
\hline Aesculus & 119 & 101 & 18 & 2 & 8 & 13 & 5 \\
\hline Acer & 55 & 38 & 17 & 2 & 0 & 16 & 1 \\
\hline $\begin{array}{l}\text { Ostale } \\
\text { Other }\end{array}$ & 158 & 125 & 33 & 6 & 8 & 27 & 9 \\
\hline Ukupno & 861 & 494 & 364 & 117 & 60 & 281 & 107 \\
\hline
\end{tabular}

\section{DISKUSIJA - Discussion}

Istraživanja provedena u ovom radu imala su za cilj utvrđivanje stepena oštećenosti urbanog drveća nastalog kao posljedica štetnog djelovanja snijega i značaja ovih oštećenja za njihovo zdravstveno stanje u narednom periodu. Ukupno je analizirano 861 stablo iz tri sarajevska drvoreda. Prema rezultatima istraživanja uočljivo je postojanje razlika u zastupljenosti vrsta drveća i njihovih uzrasta (prečnika) u navedenim objektima gradskog zelenila (tabela 1.). Najzastupljenije vrste su: lipa (Tilia sp., 388 stabala), platan (Platanus sp., 141 stablo), divlji kesten (Aesculus hypocastanum, 119 stabala) i javor (Acer sp., 55 stabala).

Rezultati provedenih istraživanja potvrđuju važnu ulogu snijega kao agensa koji mehanički oštećuje urbano drveće. Prema rezultatima istraživanja oštećenja od snijega su evidentirana na čak 364 stabla ili 42,3\% (tabela 3.). Među oštećenim stablima najviše je onih sa prelomima grana $(77,2 \%)$ a zatim prelomom debla $(32,1 \%)$ i rascjepom krošnje (16,5\%). Pri tome su višestruka oštećena zabilježena na 107 stabala (29,4\% svih oštećenih stabla).

Evidentne su razlike u stepenu oštećenosti stabala različitih vrsta drveća. Na ovakvu pojavu ukazuju VALINGER ET AL. (1993). Najmanji broj stabala sa oštećenjima evidentiran je kod divljeg kestena $(15,1 \%)$ dok je čak $90,1 \%$ platana pretrpjelo ovakve štete. Kod preostale dvije značajnije zastupljene vrste zabilježena su oštećenja na 43,6\% stabala lipe i 30,9\% stabala javora (tabela 1.). Slične intenzitete oštećenosti utvrdili su i drugi autori (ZHU ET AL., 2006). Primjenom Mc Norman Chi-square testa potvrđeno je postojanje statistički značajnih razlika među vrstama drveća u ovom pogledu $(p=2,62 \mathrm{E}-42)$.

Sniježne padavine u Sarajevu u oktobru 2009. godine desile su se u vrijeme kada većina biljaka nije odbacila list niti čak započela ovaj proces (BEUS, 2009). Ova pojava doprinijela je nagomilavanju snijega sa katastrofalnim posljedicama po urbano 
drveće. Prema SCHÖNENBERGER ET AL. (2002) klimatske promjene pogoduju nastanku kritičnih situacija za stabla urbanog drveća. Upravo učestale i nagle promjene temperature i intenziteta vjetra rezultiraju nastankom i taloženjem mokrog snijega na granama drveća. Opterećenja koja nastaju u ovakvim situacijama u kombinaciji sa pojavom širokih i asimetričnih krošnji uzrokuju lomove grana a nerijetko i prelome debala. Značaj pravilno formirane krošnje kao elementa otpornosti prema štetama od snijega naglašavaju i drugi istraživači koji su se bavili ovom problematikom (PELLIKKA I JÄRVENPÄÄ, 2003; NYKÄNEN ET AL., 1997).

Osim izraženih razlika u broju oštećenih i neoštećenih stabala prema vrsti drveća, zapaženo je postojanje razlika među ovim kategorijama i u pogledu uzrasta stabala iste vrste drveća. Na osnovu rezultata istraživanja ne postoji jasna pravilnost kod analiziranih vrsta $\mathrm{u}$ sarajevskim drvoredima (tabela 1.). Na primjeru lipe primjetno je da su značajnije oštećena stabla srednjih debljina, $40-70 \mathrm{~cm}$. Kod ostalih vrsta jače su oštećena stabla nižih debljinskih stepena, $10-40 \mathrm{~cm}$. Međutim, treba naglasiti da su to upravo i najzastupljenija stabla ovih vrsta drveća, sa izuzetkom platana. Značajnost navedenih razlika kod lipe i platana potvrđena je i provedenim statističkim analizama $(p$-Value $=0,001331, p$-Value $=0,003487)$. Ovakvi rezultati odstupaju od onih koje navode drugi autori. Moguće je da je presudnu ulogu u intenzitetu oštećenosti drveća u Sarajevu imalo prisutno lišće u vrijeme nepogode i izostanak adekvatnih mjera njege u prošlosti. Prema PETERSON (2004) stabla srednjeg uzrasta trpe manja oštećenja uzrokovana snijegom i vjetrom od tanjih ili robusnih stabala. Drveće nižih debljinskih stepena podložnije je štetama od snijega zbog procesa stabilizacije i adaptacije na raspoloživi prostor koji još traje u tom uzrastu. Zbog toga, statički loše formirana stabla bilo zbog nedovoljnog prostora ili nedostatka kvalitetne njege redovito stradaju od snijega i olujnog vjetra. S druge strane, potpuno odrasla i robusna stabla su pretrpjela ranija oštećenja od biotskih i abiotskih štetnih faktora koji umanjuju njihovu otpornost na mehanička naprezanja (savijanje). Upravo se na robusnim stablima najbolje uočava nepovoljan ishod ulančavanja štetnih agenasa. I drugi istraživači povezuju nastale povrede sa naseljavanjem mikroorganizama i insekata koji potom dodatno pogoršavaju zdravstveno stanje urbanog zelenila (TREŠTIĆ ET AL., 2008; TOMICZEK ET AL., 2008; TREŠtIĆ ET AL., 2007; DaUtBAŠIĆ ET AL., 2004; TREŠTIĆ ET AL., 2003; VALINGER I LUNDQUIST, 1994; ROTTMANN, 1985).

\section{ZAKLJUČCI - Conclusions}

Imajući u vidu rezultate ovih i ranijih istraživanja nameće se potreba ozbiljnijeg pristupa pri izboru vrste i provenijencije drveća. Zbog sve učestalijih šteta od snijega potrebno je osmisliti bolji organizacioni oblik preventivnih mjera s ciljem smanjenja oštećenja urbanog drveća. Sanacija nastalih povreda je nužno ali svakako ne i zadovoljavajuće rješenje. Različiti uzročnici truleži naseljavaju povrijeđena mjesta i u narednom periodu slabe stabilnost jedinke u prostoru ili općenito umanjuju njenu životnu kondiciju. Među gljivama koje uzrokuju trulež drveta u sarajevskim 
drvoredima naročito su zastupljene: Inonotus hispidus (Fr.) Karst., Laetiporus sulphureus (Fr.) Murrill., Schizophyllum commune Fr. i Stereum purpureum (Wild., Fr.,) S.F. Gray. Značajan broj gljiva truležnica a isto tako i štetnih insekata zahtijevaju kontinuirano i kompleksno sagledavanje pitanja zdravstvenog stanja urbanog drveća. Pri tome uvijek treba nastojati preventivnim mjerama jačati otpornost biljaka prema bolestima, štetočinama i poremećajima okoline. U tom pogledu od posebne su važnosti pored navednog i kvalitet stanišnog prostora, mjere njege i kontinuiran zdravstveni pregled.

\section{LITERATURA - References}

Beus, V. (2009): Katastrofalni snjegolomi drveća u urbanom zelenilu Sarajeva. Naše šume, 16-17.

DAUTBAŠIĆ, M.; UsČUPLIĆ, M. I TREŠTIĆ, T. (2004): Zdravstvena slika stabala lipe u aleji "Vilsonovo šetalište" u Sarajevu. Drugi Simpozij poljoprivrede, veterinarstva, šumarstva i biotehnologije. Bihać, Knjiga sažetaka, str. 147.

Diminić, D., HRAŠOVEC, B. (2005): Uloga bolesti i štetnika pri odabiru drveća u krajobraznoj arhitekturi. Agronomski glasnik, 67(2-4): 309-325.

JACKSON, M.C. (1977): A method for estimating the probability of occurrence of snow water equivalents in the United Kingdom. Hydrological Sciences Bulletin 22: 127-142.

KANTIĆ S., MuJeZINOVIĆ O., DAUTBAŠIĆ M. I TREŠTIĆ T. (2009): Istraživanje minera lista na zelenim površinama urbanih prostora. VI Simpozijum o zaštiti bilja u BiH, Tuzla, Zbornik rezimea, str. 23-24.

LJUJIĆ-MIJATOVIĆ T. I MRdović A. (1988): Proizvodnja cvijeća i ukrasnog bilja, Univerzitetska knjiga, Sarajevo.

MATOŠEVIĆ, D. (2003): Štetna entomofauna drvenastih biljnih vrsta urbanog zelenila grada Zagreba. Magistarski rad. Zagreb: Šumarski fakultet.

MATTHEWS, J.D. (1989): Silvicultural systems. Oxford. 284 p.

Megahan, W.F. I Steele, R. (1987): An approach for predicting snow damage to ponderosa pine plantations. Forest Science 33(2): 485-503.

NOROKORPI, Y., I KÄRKKÄINEN, S. (1985): Maaston korkeuden vaikutus puusto- ja kasvupaikkatunnuksiin sekä tykkytuhoihin Kuusamossa. Summary: The effect of altitude on stand and site characteristics and crown snow-load damages Kuusamo in Nothern Finland. Folia Forestalia 632. 26 p. (In Finnish).

NykÄnen, M.L., Peltola, H., Quine, C., KellomäKI, S. I Broadgate, M. (1997): Factors affecting snow damage of trees with particular reference to European conditions. Silva Fennica 31: 193-213. 
PellikKA, P. I JÄRVEnPÄÄ, E. (2003): Forest stand characteristics and wind and snow induced forest damage in boreal forest. In Ruck, B., Kottmeier, C., Mattheck, C., Quine, C. \& Wilhelm, G. (eds.). Proceedings of the International Conference: Wind Effects on Trees. Published by Lab Building, Environment Aerodynamics, Institute of Hydrology, University of Karlsruhe, Germany. p. 269-276.

Peltola, HNyKÄnen, M-L. I KellomäKI, S. (1997a): Model computations on the critical combination of snow loading and windspeed for snow damage of Scots pine, Norway spruce and birch sp. at stand edge.

PeRTTILÄ, P. (1987): Myrsky- ja lumituhojen esiintyminen sähkölinjoilla. Inventointi ja käsittelyohjeet. Metsänarvioimistieteen pro gradu-tutkielma. Helsingin yliopisto. 63 p. (In Finnish).

Peterson, C.J. (2004): Within-stand variation in windthrow in southern boreal forests of Minnesota: Is it predictable? Canadian Journal of Forest Research 34: 365375.

RotTMAnN, M. (1985): Schneebruchschäden in Nadelholzbeständen. Beiträge zur Beurteilung der Schneebruchgefährdung, zur Schadensvorbeugung und zur Behandlung schneegeschädigter Nadelholzbestände. J.D. Sauerlander's Verlag, Frankfurt am Main. 159 p.

SCHÖNENBERGER, W. (2002): Windthrow research after the 1990 storm Vivian in Switzerland: objectives, study sites, and. projects. Forest Snow Landscape Research 77: 9-16.

SOLANTIE, R. (1994): Effects of weather and climatological background on snow damage of forest in southern Finland in November 1991. Silva Fennica 28: 203-211.

Tomiczek, C., Diminić, D., Cech, T., Hrašovec B., Krehan H., Pernek, M., Perny, B. (2008): Bolesti i štetnici urbanog drveća. Jastrebarsko, Zagreb: Šumarski institut, Šumarski fakultet.

TREŠtić T., DAUTBAŠIĆ M., MuJeZINOVIĆ O. (2008): Zdravstveno stanje zelenila na području Vogošće. Društvo za zaštitu bilja u BiH, 5. Simpozij o zaštiti bilja u $\mathrm{BiH}$, Sarajevo, Zbornik rezimea, str. 54.

TREŠTIĆ T., DAUTBAŠIĆ M., MUJEZINOVIĆ O. I LIKIĆ A. (2007): Uticaj oštećenosti stabala na opće zdravstveno stanje sastojine. IV Simpozijum o zaštiti bilja u BiH, Teslić, Zbornik rezimea, 2007.

TReŠtić, T., Usčuplić, M., Dautbašić, M., Kunovac, S. I Ponjavić, M. (2003): Sistem praćenja štetočina i uzročnika bolesti na šumskom i urbanom zelenilu. Prvi simpozij poljoprivrede, veterinarstva i šumarstva "Strategija razvoja domaće proizvodnje”. Neum. Zbornik radova, str 213-220 
VALINGER, E. I LUNDQVIST, L. (1994): Reducing wind and snow induced damage in forestry. Sveriges lantbruksuniversitet, Institutionen för skogskötsel, Rapporter 37. $11 \mathrm{p}$.

VALINGER, E. LUNDQVIST, L. BONDESSON, L. (1993): Assessing the risk of snow and wind damage from tree physical characteristics. Forestry 66(3): 249-260.

WiLLISTON, H.L. (1974): Managing pines in the ice-storm belt. Journal of Forestry 72(9): 580-582.

ZAR, H. J., (1996): Biostatistical analisys. Prentice-Hall Internacional, Inc.,USA.

ZHU, J., LI, X., LIU, Z., CAO, W., GONDA, Y. I MATSUZAKI, T. (2006): Factors affecting the snow and wind induced damage of a montane secondary forest in northeastern China. Silva Fennica 40(1): 37-51.

\section{SUMMARY}

The aim of this research was to analyze the health status of urban trees with special reference to mechanical damages caused by harmful effect of snow. The heavy snow in October 2009 caused considerable damages of trees in Sarajevo. Research was carried out in three important Sarajevo's avenues: Vilsonovo šetalište, Bulevar Meše Selimovića and Alipašina ulica. According to the research methodology, every tree was characterized by tree species, breast diameter and type of damage(s). The tree was classified as "damaged" if any of following symptoms was present: stem fracture, split of the crown or fracture of branch. Total 861 trees were analysed. The most represented tree species were Lime-tree (Tilia sp., 388 trees), Plane tree (Platanus sp., 141 trees), Horse-chestnut (Aesculus hipocastanum, 119 trees) and Maple (Acer sp., 55 trees).

According to the results of the research, considerable damages of trees caused by snow was observed. The most damaged species has been Platanus $(90,1 \%)$. The percentage of damaged tree of other species are Tilia $(43,6 \%)$, Acer $(30,9 \%)$ and Aesculus $(15,1 \%)$. The value of Mc Norman Chi-square test indicates a statically important difference of tree species resistance to damages caused by snow ( $p$-Value $=$ 2,62E-42). Also the differences in distribution of damaged trees per species and diameter class were noted. Lime-trees of the middle diameters have been more susceptible to damage than thinner and thicker ones $(p$-Value $=0,001331)$. Damaged trees of other species are mostly in the thinner class.

It is predicted that the damages of trees will play suitable inputs for a number of wood decaying microorganisms and insects in future. Better measures of damaged and other trees in Sarajevo are needed. Proper selection of tree species, improvement of habitat area of each plant, quality care of trees and a continuous and systematic health monitoring could prevent future catastrophic damages of urban greenery. 